Franz Flögel, Gelsenkirchen

\title{
The new realist ontology
}

\author{
Metatheoretical foundation for research of modern finance?
}

\begin{abstract}
Financial geographers utilise realist economic and rather anti-realist sociologic theories. Yet, theories from both traditions seem to contradict each other metatheoretically. The new realist ontology promises to settle this metatheoretical contradiction by preserving the realist claim on trueness with the concept of fields of sense without rejecting the plurality of human perspectives. This paper exemplarily demonstrates that realist and rather anti-realist theories accord with the new realist ontology. Further, using an empirical example of bank-based small-firm lending it illustrates that the combined use of theories from both traditions advances our understanding of modern finance.
\end{abstract}

Keywords: new realist ontology, financial geography, banking and small-firm finance, performativity of economics

\section{Introduction}

Numerous geographers utilise economic theories like institutional economic or post-Keynesian theories in financial geography (e.g. SCHAMP et al. 1993; KLAGGE/MARTIN 2005; ZADEMACH 2009; GÄRTNER 2009; HANDKE 2011; THOMI/ OsSENBRÜGGE 2011; SCHEUPLEIN 2013; ZADEMACH 2014). Other geographers employ theories from sociology and related disciplines (e.g. HALL 2006; JÖNS 2006); theories from the research field of the social studies of finance (SSoF) are especially popular (BERNDT 2011; OUMA 2012; CHRISTOPHERS 2013; OUMA/BläSER 2015 in this issue). SSoF emphasise the constructiveness of markets whereby economic theories profoundly influence market construction (CALLON 1998; MAcKenZIE 2006; BeRnd/BöcKLER 2009). MacKenzie $(2006,12)$ claims: "[economics is] an active force transforming its environment, not a camera passively recording it". Thus, financial geographers apparently utilise both economic theories and SSoF theories that critique these economic theories, sometimes even applying both together in one account (GÄRTNER/FLÖGEL 2013). This paper discusses whether this combined use of seemingly opposing theories causes contradictions on a metatheoretical level or can rather advance understanding within financial geography.

Empirical studies influenced by SSoF advance the understanding of failures in modern finance and helped to explain the financial crisis of 2007/08 (Christophers 2013; MACKENZIE 2011; Engelen et al. 2010; Berndt 2011). Nevertheless, economic theories like institutional economics and new banking theories, with their notion of e.g. information asymmetry, agency problems, shape our understanding of why geography matters in finance (KLAGGE 2009; GÄRTNER 2009; HANDKE 2011; ZADEMACH 2014). Therefore, to abandon one field of theories in favour of the other would involve an explanatory loss for financial geography and restrict its connectivity to neighbouring disciplines.

The seemingly metatheoretical contradiction emerges because economic theories are grounded in a realistic understanding of sciences, i.e. economics should research how the economy works and describe this in models and theories. Approaches in SSoF assume rather anti-realistic positions, i.e. there is no independent real economy out there to be discovered, humans (and scientists) rather construct economies. In this way the theory usage of financial geography corresponds to the general division of theory in human geography into realistic and rather anti-realist approaches (EGNER 2010; MATTISSEK et al. 2013; SteINER 2014a). Thereby, theories of SSoF popular in financial geography - like Actor-network theory (ANT) (JöNS 2006) and the theory on the performativity of economics (Berndt 2011; Ouma 2012; Christophers 
2013) - can be counted as post-dualist theories (STEINER 2014a) as they consider non-human objects in the construction of reality.

To address this seemingly metatheoretical contradiction this paper introduces the new realist ontology. It discusses whether this new ontology accords to a realist and a rather anti-realist theory popular in the geography of finance. Reflecting on metatheory is not new in human geography (WERLEN 1997; JÖNS 2006; STEINER 2014a; short overview in WOODARD/JONES 2009). However, the new realist ontology and its fields of sense, as put forward by the German philosopher Markus Gabriel and others (e.g. FERRARIS 2014), are new. Not without self-confidence, GABRIEL (2013) claims that the new realist ontology overcomes postmodern (anti-realistic) nihilism without falling back to a naïve realism. To accomplish this, GABRIEL (2015) outlines a very tolerant ontology and justifies epistemological pluralism but introduces the concept of fields of sense, whereby true facts can be identified within the fields of sense. Ontology is the "systematic investigation into the meaning of "existence"" (GABRIEL 2015, 187), thus addressing the question of what in principal exists. Ontology relates to epistemology, i. e. "the systematic investigation into the meaning of "knowledge" ' (GABRIEL 2015,318 ), thus addressing the question of how humans can truthfully know what exists. Whereas some metatheories merge ontology and epistemology and either privilege physical things or human thoughts, the new realist ontology admits the existence of both without privileging one or the other ontologically (GABRIEL 2014). Hence the new realist ontology promises to accord with both realistic and rather anti-realistic theories.

In the following the new realist ontology is introduced in differentiation to (materialist) metaphysics and radical constructivism. Then the new realist ontology is related to two theories popular in the geography of finance: the realist theory on distance and small-firm lending and the rather anti-realist theory on the performativity of economics. The following section looks at an empirical case and indicates that the combined use of both theories advances our understanding of bank lending to small firms. As the new realist ontology can make up the ontological basis of both theories, their combined use causes no metatheoretical contradiction. The conclusion points out that the new realist ontology advises the use of varying theories and methods, which is usual in financial geography.

\section{The new realist ontology}

The philosophers Maurizio FERRARIS (2014), Markus GABRIEL (2013) and others use the term new realism to bring together an international debate in philosophy and related sciences that is dissatisfied with the constructivist postmodern paradigm (GABRIEL 2014). The following short discussion of the new realist ontology focuses on the work of GABRIEL $(2013 ; 2014 ; 2015)$. According to GABRIEL (2013), postmodern radical constructivism (global anti-realism) assumes that there are no objective facts and that all facts are constructed by (scientific) discourses and research methods. Hence, humans cannot recognise the world, everything they recognise is manmade and represents just one perspective among others. Following GABriel (2013), the opposite of this radical constructivist perspective are metaphysic worldviews that explain everything with a single (material) theory (old realism). The popularity of these perspectives continues and is even increasing at present (GABRIEL 2014). One interpretation of neuroscience that claims that all types of awareness, e. g. feelings, thoughts and dreams, are just states of the brain exemplifies a metaphysic worldview. Accordingly, the world differs from its appearance to humans and just consists of materiality and its physical and chemical states (GABRIEL 2014). The notion that humankind remains very unimportant in the endless universe represents another example of material metaphysics.

In contrast to these two perspectives GABRIEL (2013) posits the new realist ontology by using one simple example. Consider the mountain Vesuvius as observed by three people from two positions on earth ( $1, p 2$ and $\mathrm{p} 3)$. In this scenario, (material) metaphysics argues that only Vesuvius exists. Radical constructivists would argue that three objects exist: $p 1$ 's Vesuvius, p2's Vesuvius and p3's Vesuvius. According to this worldview it might be possible that Vesuvius exists independently of the observations of $\mathrm{p} 1$, p2 and p3; however one can never be sure about this (EGNER 2010). Now GABRIEL (2013) argues that it is reasonable to assume that actually four objects exist here: Vesuvius and the three perspectives on Vesuvius (p1, p2 and p3). This is the perspective of the new realist ontology.

Following GABRIEL (2013), this four-objects perspective represents the most promising one as the other two perspectives make unjustified simplifications: "[...] metaphysical (old) real- 
ism is exclusively interested in the world without spectators, whereas constructivism is exclusively interested in the world of the spectators [...] (GABRIEL 2015, 11). Consequently, as both assumptions contradict human experience, the four-objects perspective convinces most (GABRIEL 2013). It is equally a fact that $\mathrm{p} 1$ has a specific perspective on Vesuvius which may stimulate emotions, ideas and thinking. It differs from the $\mathrm{p} 2$-perspective and especially from the p3-perspective that looks at Vesuvius from another location on earth. Yet, it is also a fact that all people who are able to see will perceive a thing (a massive thing that geologists identify as a volcanic mountain and that is called Vesuvius in our time), if they take the p1-position and if weather conditions remain constant. Accordingly, the new realist ontology sticks to the realist position that, in principle, humans have direct access to objects (e.g. things) with their senses (FERRARIS 2014; GABriel 2015). They are not only entangled in representations of objects. Thus, for example, how something looks is a modally robust fact of that thing and not only a human's representation of it (GABRIEL 2015, 350 ). Thereby human representations of and perspectives on this object also exist as further objects.

To date the new realist ontology has rejected privileging either the world of things or the world of thoughts, a perspective several geographers have called for (MURDOCH 1996; JÖNS 2006; STEINER $2014 b)$. Furthermore, the approach admits that humans have the ability to sense material things similarly, a position empirical research builds upon. Thereby human delusions and false conclusions, of course, occur. However, as the new realist ontology adds more objects (the universe of things) to all human perspectives one actually end up with more objects than with radical constructivism. Unfortunately, so far this argumentation does not help to identify true statements, i.e. if all perspectives on Vesuvius contradict each other, which of these perspectives is true? To handle this problem Gabriel introduces the concept of fields of sense (FoS). Everything that exists does so in a certain FoS, whereby it is sufficient for something to generally exist to appear in any one of the many fields of sense (GABRIEL $2015,65)$. Therefore, the new realist ontology is extremely tolerant. It shall not rule out "in advance that things that seem to exist actually exist" (GABRIEL 2015, 297). Hence, the question is always not whether something exists, e.g. whether something is true or not, but in which
FoS something exists, i.e. in which FoS something is true (GABRIEL 2013).

"The fields of sense characterise what exactly it is for something to appear in them" (GABRIEL $2015,44)$, i.e. by which property or sense objects are individuated in the FoS. Furthermore, FoS themselves only exist because they appear as objects in other FoS. Thus, their senses that individuate the objects appear as objects in other FoS, whereby these individuating senses are not proper properties ${ }^{1}$ of the objects in the FoS. This can be illustrated with an example. Consider a FoS that encompasses circular and square objects. Shape defines the individuating sense of the objects in this FoS. However, shape itself is not a proper property of the objects in this FoS because all objects are shaped, thus they cannot be distinguished by the property shape. Yet, shape counts as an object in the FoS of the characteristics of (physical) things, along with e.g. colour, size, weight. Note however, that characteristics of (physical) things is not the only FoS where shape, colour, size and weight appear as objects, for example they also appear as objects in this paper in the German Journal of Economy Geography.

Gabriel's FoS ontology highlights that "there is no possible rule singling out all fields of sense. In other words, fields of sense are really individuated without recourse to an overall principle of individuation" (GABRIEL 2015, 243). Some FoS are individuated by human fields of vision, others by discursive practices, by physical relationships, by disciplinary boundaries or by artistic work. This leads directly to the final notion of the new realist ontology, the no-world claim. Gabriel $(2013 ; 2015)$ argues that there is no FoS of all FoS, i.e. the all-encompassing world does not exist. "There is no field of sense that is ontologically absolutely privileged" (GABRIEL 2015, 298). This can basically be explained by the fact that this all-encompassing FoS would be outside of itself and hence contradict the allencompassing claim. "Another way of putting this is to assert that there is no such thing as the meaning of it all and that this is the reason why there is no such as it all" (GABRIEL 2015, 194).

With the help of FoS the claim to explain all put forward by (material) metaphysic worldviews is unmasked as a confusion of different FoS. Taking the universe's metaphysics as an example, the universe belonging to the FoS of physics is simply not everything, e.g. Goethe's Faust 
or banks also exist. Indeed, Faust and savings banks can be located in the universe (i.e. on planet Earth which belongs to the solar system that is part of the Milky Way ...) and thus in the FoS of physics. However, this does not help to interpret Faust or to understand banks' lending practices. Similarly, Faust or the Handbook of Corporate Credit Business (AHNERT et al. 2009) would not help to understand the universe.

Let us apply this new realist ontology to a topic of financial geography by considering the statement: Spatial distance influences bank-based small-firm lending. Is this true or not? One easily asserts that this statement exists, at least as a written sentence in this paper. It is also easy to find out that sentences with a similar meaning exist in several other papers (e.g. BERGER et al. 2005; AlEsSANDRINI et al. 2009), whereas other papers (e.g. UCHIDA et al. 2012) and theories (e.g. neo-classic) assert the opposite. Obviously this can continue for a while. However, most financial geographers want to know whether this sentence exists as a true statement about bank-lending practices to small firms. Hereby geographers would presumably also add a region of the earth and (sometimes) a time to this sentence, as they know that context matters. Answering this question causes several difficulties as, for instance, several (conflicting) theories state why distance may or may not matter in small-firm lending. Hence no single parameter exists that one can unambiguously sense. GABRIEL $(2015,242)$ admits that "[m]any fields [of sense] are hybrids, and what is mixed in them cannot be anticipated a priori. There is change and creativity. There are also different forms of temporality, change and alteration, [...]." Thus, to find out something about these "hybrid fields" requires empirical enquiries (GABRIEL 2015, 246). Having said this, there cannot be one single epistemology for empirical research either, because of the lack of an overall principle for individuating FoS (no FoS of all FoS). Rather GABRIEL $(2015,329)$ endorses epistemological plurality, i.e. a plurality of knowledge. ${ }^{2}$

In its demand for plural knowledge the new realist ontology equates to radical constructivist accounts, yet with the exception that the senses that individuate FoS are not only human constructs. For example, for an enquiry into the age of the earth knowledge of the FoS of geology and related sciences takes precedence and not the holy bible. In this respect КосH (2014) criticises a non-hermeneutic interpretation of the new realism and demonstrates that human (lexical) reference is necessary to distinctively individuate objects (e.g. FoS). Therefore, he concludes that the new realism can only be hermeneutic and realistic (КосH 2014, 243), whereby he does not deny the real existence of things and human ability to sense them (КосH 2014, 234). However, radical constructivists deny precisely this, arguing that humans necessarily gain all knowledge with their senses (including thinking). Therefore, principal errors in our sensing, e.g. adulterant representations about objects, would prohibit sensing objects as they are (EGNER 2010). Hence, absolute or objective knowledge about objects cannot exist but human representation filters our senses.

Gabriel's response to radical constructivism accords with other realist philosophers (e.g. BoGHOSSIAN 2013). He points out, for instance, that the rejection of objective knowledge itself relies on one objective and true fact, the fact that humans in general fail to sense things as they are. The new realist ontology rules out this metaphysic claim. "If knowledge cannot be unified by specifying any alleged universal and substantial structure holding knowledge as such together, there correspondingly is no position from which to undermine knowledge in one stroke. Epistemological pluralism, therefore is a bulwark against scepticism." (GABRIEL 2015, 354) To my reading, Gabriel's response to radical constructivism nevertheless fails to finally settle this dispute due to the maintenance of the agnostic position that humans cannot be sure that they sense things in a way that is at least partly true (see STEINER 2014a for the agnostic position). However, the new realist ontology takes a pragmatic position and assumes that humans have some sense of things independent of their representation of them - an assumption that the post-dualist theory ANT also relies on, for instance (CALLON 1999 [1987]).

To sum up, the new realist ontology takes a very tolerant position on what exists (basically everything) and advises epistemological plurality to gain knowledge of objects. To facilitate the realist notion of true facts, GABRIEL (2013, 2015) introduces FoS, whereby something exists if it appears in a FoS. FoS themselves only exist because they appear in other FoS, whereby the individuation of (and in) FoS is not only a construct of human cognition but is governed by plural senses. Hereby, no overall rule exists to individuate FoS (no-world claim). Against this 
background, a theory must meet two criteria to accord with the new realist ontology. Firstly, the theory should not be grounded on radical constructivism, i.e. totally rejecting the human capacity to sense true facts. Secondly, the theory should also not be metaphysical, i. e. forwarding all-encompassing or all-explaining claims.

\section{New realist ontology and theories in financial geography}

This section discusses whether theories from economics and SSoF popular in financial geographies accord to the new realist ontology or contradict one of its two criteria. More precisely, it discusses the realist economic theory on distance in small-firm lending and then turns to SSoF theory on the performativity of economics according to MacKenzie. As outlined in the introduction, both theories seemingly differ with respect to their metatheoretical foundation, furthermore the latter theory accuses economic theories of constructing rather than describing the economy.

\section{Distance in small-firm lending and new realism}

Scholars frequently link spatial distance to bankbased small-firm lending because it hampers the transmission of information (STEIN 2002; Berger et al. 2005; KlagGe/Martin 2005; AgARWAL/HAuswald 2007; AlessandRINI et al. 2009; GÄRTNER/FLÖGEL 2013). Following Stein (2002) and Alessandrini et al. (2009), the theory basically states that so-called soft information is difficult to transmit across distance as soft information "cannot be directly verified by anyone other than the agent who produces it" (STEIN 2002, 1982). Low spatial distance eases the transmission of soft information because it facilitates face-to-face interaction and supports other forms of proximity, like social embeddedness, between actors. Hence, banks that operate over a short spatial distance obtain more soft information from their customers and thus gain informational advantages in comparison to more distant banks. Not only metric customer-to-branch distance is relevant, but also the decision-making power of local staff as soft information must reach the decision makers (STEIN 2002; AlESSANDRINI et al. 2009). As small firms are especially informationally opaque, low distance becomes particularly relevant in smallfirm lending (HANDKE 2011).
This theory on distance and small-firm lending does not contradict the new realist ontology, which cannot surprise as it represents a realist theory. It actually combines objects from the FoS of physics, i.e. the metric distance between actors on the surface of the earth (spatial distance), and objects from human sociality, i.e. the way humans verify soft information for which face-to-face interaction still appears to be relevant. In line with the first criteria of the new realist ontology the theory can be a true or false description of its FoS (bank-based small-firm lending). Only empirical investigation can determine the trueness of the theory (ALESSANDRINI et al. 2009), whereby the context most likely matters. Furthermore, neither does the theory on distance and small-firm lending encompass a metaphysic claim (second criteria), i. e. it clearly restricts its explanatory power. Even in terms of its FoS, the theory only demands moderate explanatory power and leading supporters highlight that several other facts are equally relevant in order to understand bank-based lending to small firms (ALESSANDRINI et al. 2009). Therefore, a combined approach with other theories causes no difficulties.

\section{The performativity of economics and new realism}

Several financial geographers use the theory on the performativity of economics (BERNDT 2011; CHRISTOPHERS 2013), especially MacKenzie's accounts as he explicitly discusses financial markets. MacKenzie $(2006,12)$ claims that economics construct rather than research the economy. The well-known study of MACKenZIE/MiLLO (2003) on the Chicago option market and the Black-Scholes option price model evidently justifies this claim. The Black-Scholes model calculates option prices in relation to the underlying stock prices. The economists Black, Scholes and Merton deducted the model on the basis of unrealistic assumptions (MAcKeNZIE 2006). Whereas the model was initially not particularly good in predicting the actual option market prices, its usage by market practitioners in arbitrage changed the prices in the way the model had predicted. MACKENZIE (2006) names such a development "Barnesian" performativity. With the (option) market crash of 1987 the good conformity of actual and model prices was eventually destroyed, as market practitioners stopped using plain model results for trading. Consequently, "Barnesian" performativity of the Black-Scholes models ended (MACKENZIE 2006). 
For MACKenZIE $(2006,19)$ "Barnesian" performativity only makes up one subset of his classification concerning how economics becomes incorporated into the economy (see Fig. 1). All aspects of economics that not only academic economists but also practitioners of the economy perform (e.g. managers, supervisors) are called "generic" performative. If this application has any effect on economic processes, i.e. if it makes a difference, then MACKENZIE (2006, 18) names this "effective" performativity. "Barnesian" performativity differs from "effective" performativity because it does not have any effect but the "processes are being altered in ways that bear on their conformity to the aspect of economics in question" (MACKENZIE 2006, $18 \mathrm{f}$.). As the term indicates, counterperformativity accounts for the conversion of "Barnesian" performativity and means "that the effect of the practical use of a theory or model may be to alter economic processes so that they conform less well to the theory or model" (MAcKenZIE 2006, 19). "Barnesian" performativity and counterperformativity count as strong meanings of performativity, as they alter economic results in the way (or contrary to the way) that the theories/ models depict because of the model depiction (MacKenZIE 2006, 24).

Fig. 1: Different forms of the performativity of economics

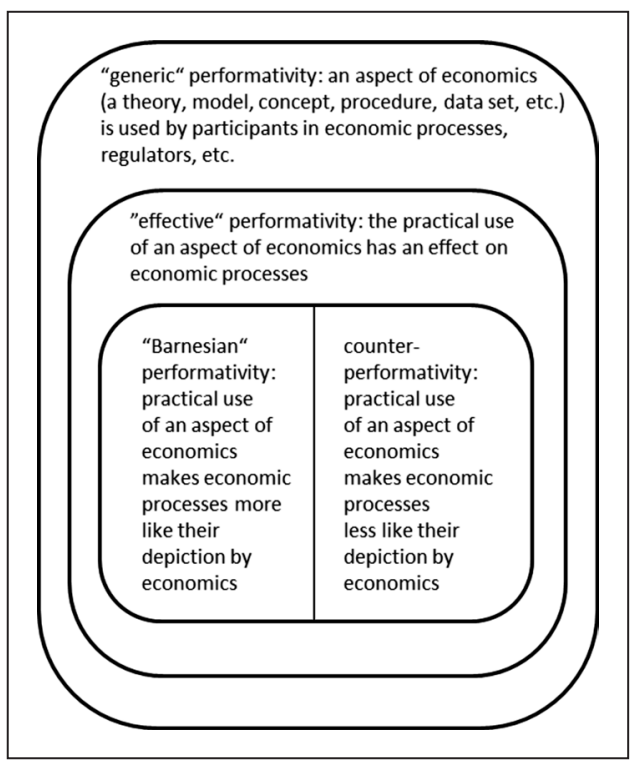

Source: MACKenZIE 2006, 17
In modern finance, rating models are prone to performative effects (RÓNA-TAS/HISS 2008; PoON 2007). Banks and other financial actors rely heavily on rating models to predict the probability of default (PD), e.g. the likelihood that a firm defaults within the following year. With their prediction of $\mathrm{PD}$, rating models can cause strong performative effects if they systematically over- or underestimate the actual default probability of firms. If a rating model calculates a poor rating score (PD) for a firm then the bank of the firm in question may become reluctant to lend as it expects a high likelihood of firm default. This in turn can cause a liquidity shortage for the firm and hence cause firm default. If the firm only defaults because of the poor rating score and the following reduction of credits, the rating score causes "Barnesian" performativity (Fig. 2 illustrates this for firms in crisis). The more acute the crisis becomes, the higher the probability that a firm defaults (lower curve in Fig. 2). The bank's rating model detects the firm's crisis, i. e. the rating score decreases as the crisis increases. If the model's rating score overestimates the firm's crisis, i.e. the firm's PD, and the bank acts accordingly and cuts the credit lines more radically than it would have done if aware of the actual default likelihood, this may actually cause firm default (upper curve in Fig. 2). The difference between the upper and lower curve make up the effect of "Barnesian" performativity.

Fig. 2: Rating model and "Barnesian" performativity

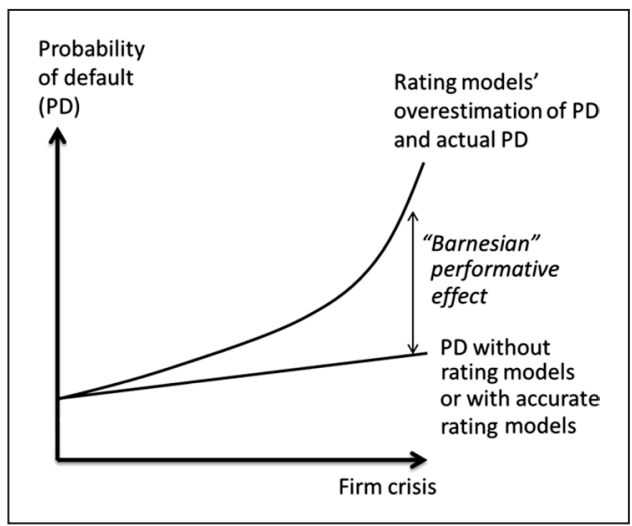

Source: own draft

Counterperformativity arises, for example, if the rating model is so important for credit decisions that users manipulate the inputs of the model to 
gain a better rating score without reducing the true PD of firms. In this case, the bank grants loans that otherwise would never have been granted if the bank had known the actual risk of firm default (Fig. 3). Thus, the predictive power of the rating models becomes undermined. This means that the rating model underestimates the risk precisely because it is used in actual economic processes, as otherwise model users would have had no incentive to manipulate the model inputs. Empirical studies well document counterperformativity in the US subprime mortgage crisis, where consumers manipulated the FICO score to obtain credits, downgrading the predictive power of the score (RÓNA-TAS/HISS 2008; RAJAN et al. 2010).

Fig. 3: Rating model and counterperformativity

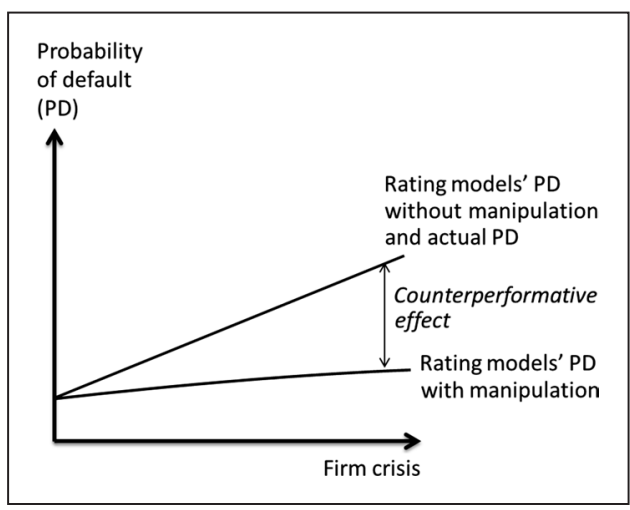

Source: own draft

Detecting strong performativity causes profound empirical difficulties as a direct comparison between market results with and without model use is normally not possible in the actual economy (MacKenzie 2006). In this sense, MacKenZIE/MiLLO (2003) only managed to identify the Black-Scholes model's "Barnesian" performativity ex post because of the singular stock market crash in 1987. Banks' empirical validations of their rating models are also not able to reliably identify "Barnesian" performativity. With socalled "back tests" banks check whether model predictions equal actual default. However, as "Barnesian" performativity causes actual firm default, back testing cannot validly detect "Barnesian" performativity. Counterperformativity is detected by back testing in so far as it reveals rating models' underestimation of PD. If banks alter their rating model according to the coun- terperformative effect, executing rating without manipulation would lead to an overestimation of firms' PD.

Turning to the new realist ontology, does the theory of the performativity of economics accord with or rather conflict this ontology? As explained above the theory states that theories/ models can influence actual market results with their depictions. Hereby "Barnesian" performativity alters the actual market results in the way the model has depicted (upper curve in Fig. 2). This, in turn, implies that there must be a possible market result independent of the model depiction (lower curve in Fig. 2). Otherwise there cannot be a "Barnesian" performative effect (see also Svetlova 2012). ${ }^{3}$ Hence, MacKenzie's theory on the performativity of economics only makes sense if both - possible market results independent of the model and the model's depiction of market results that causes strong performativity - exist. This is precisely the ontological claim of the new realist ontology. In fact, on the one hand, radical constructivist positions appear insufficient because they fail to capture the true existence of possible market results without model intervention. This is the market results as an effect of actual economic processes minus the model's performative effect (lower curve in Fig. 2). On the other hand, material metaphysic worldviews are likewise insufficient because they deny the existence of human perspectives on the world (i. e. theories/models) that can cause "Barnesian" performativity. Thus, for example, they deny that economic models do not only describe economic processes but can also alter them.

This is not to deny that the comparison between actual market results, possible market results without model usage, and the model's prediction of market results causes profound empirical difficulties (MACKENZIE 2006, 21 ff.). "It is therefore tempting to set the issue aside, and to abandon the strongest meanings of performativity (Barnesian performativity and counterperformativity). However, to do that would involve also abandoning a central question: Has finance theory helped to create the world it posited - for example, a world that has been altered to conform better to the theory's initially unrealistic assumptions?" (MACKeNZIE 2006, 24). In this regard SvetLova (2012) argues that strong performativity only rarely occurs and that whether a model causes strong performative effects is influenced by the intuitional integration of the 
model into business practices (see also MACKENZIE 2011). This argument does not oppose MacKenzie's performativity theory as the theory only claims that economic models can (not must) become strongly performative in the economy. Thus, MacKenzie's theory on the performativity of economics advances only moderate claims on its FoS (the use of economic models in the economy) and therefore also accords with the second criteria of the new realist ontology. Whether an economic theory becomes strongly performative or not is an empirical question, and certainly not an easy one.

\section{The new realist ontology and empirical works - the case of bank lending to small firms}

The previous section has demonstrated that the theory on distance in small-firm lending and the theory on the performativity of economics accord with the new realist ontology. This section considers whether a combined use of both theories in empirical research advances our understanding of modern finance. The focus here is therefore on an ethnographic study that compared bank-lending processes to small- and medium-size enterprises (SME) in Germany. The aim of the study was to identify differences between the credit-granting practices to SME of decentralised and centralised banks. The study raised this question against the background of banking regulations (e.g. Basel II) and centralised credit-rating systems that apparently standardising and homogenising the way in which banks evaluate firms and grant credits. Consequently, the question of whether differences in the spatial organisation of decentralised and centralised banks still matter in modern banking was at the heart of the analysis. The empirical approach involved a two-month full-time participant observation at a (decentralised) savings bank and 40 expert interviews with a (centralised) big bank and several other big and savings banks as well as related organisations.

The following sections focus on two aspects of the empirical study: firstly, the micro-geography of the savings bank's branch design and its impact on the bank-firm relationship; secondly, the usage of rating systems by the savings bank and the big bank and their proneness to performativity. Then the additional benefits of the new realist ontology and the combined use of both theories in empirical research are discussed.

\section{Bank-firm relationship and the micro-geogra- phy of distance}

Apparently, the transmission of soft information does not simply depend on spatial distance but on the relationship and communication between humans. Economists and economic geographers have discussed the relationship between banks and firms by contrasting relationship banking and transaction-oriented banking (ВоОт 2000; HANDKE 2011). In relationship banking, banks and firms cooperate closely. In contrast, the relationship in transaction-oriented banking remains rather distant. Relationship banking normally implies spatial proximity between banks and firms, which is of little importance in transaction-oriented banking. The ethnography at the savings bank has clearly shown that the bank's customer advisors have different degrees of proximity to their SME customers. Some customer relationships become very close and under certain circumstances lead to almost daily communication between customer advisors and customers. Again, other relationships remain rather distant, like in one relationship in which the savings bank was only a minor one of the many banks used by the firm in question.

The proximity of the customer relationship depends on customer advisors' perceptions of their customers and vice versa. The customer advisors assess the personal creditworthiness of a firm's management, e.g. their management skills, integrity, personal living conditions etc. In the observed savings bank the customer advisors made very critical assessments of the personal and management characteristics of some customers in existing business relationships. For example, one manager had performed badly in a property development project that was financed by the savings bank. When this manager asked his customer advisor for a credit to develop a new property on the telephone, she was very reserved and asked for many additional documents instead of offering a personal meeting. The customer advisor indicated that she would be happy if the customer asked another bank to finance his project, but at the same time she did not want to reject him harshly in order not to compromise the existing loan contracts.

Several other reasons were observed as to why customer advisors prefer to avoid personal contact with their customers. One reason is that customer advisors wish to avoid renegotiating existing contracts due to their fear of giving in 
to customer demands. In this context customer advisors also want to avoid unpleasant verbal conflicts in face-to-face meetings. Other reasons to delay personal contacts are that the bankers have not yet made an internal decision on how to react, or currently just have no time to answer. The participant observation in the customer advisor team showed that customer advisors face difficulties in avoiding face-to-face interactions because of the high accessibility of their offices.

The micro-geography of the customer advisor offices at the savings bank is illustrated in Fig. 4. The customer advisor team has four offices and a meeting room. Two constructional features cause the high accessibility of the customer advisors. Firstly, all doors to the second floor of the counter hall remain unlocked (Fig. 4) and customers can easily access the second floor via a large freestanding staircase in the middle of the counter hall. Therefore, customers very frequently drop by unannounced. Secondly, as indicated in Fig. 4, the offices open on to the busy main street and a large glass front allows a view into the offices from the outside. Curtains make sure that no details can be observed but, nonetheless, any customer can see at a glance from the street if her or his customer advisor is at her or his desk. Due to this micro-geographical design of the branch, customer advisors are only able to avoid personal telephone communication. The customer advisors highlighted several times how difficult it was to focus on single cases because of frequent interruptions by the telephone and visiting customers.

The closeness of the relationship between firms and customer advisors depends on several factors including, importantly, the perspective with which each views the other. However, the physical design of the branch hampers customer advisors' ability to avoid personal encounters. Thus customers can suddenly pop into the office and ask their customer advisors what is going on. The customer advisors are forced to interact with the customers and take a position. This micro-geographical accessibility can be a relevant aspect of the distance between banks and firms. It restricts the ability of banks (i. e. customer advisors) to ignore the demands of their customers and may lead to more decisions in favour of the customer. ${ }^{4}$ Interestingly in this regard, the customer advisors were comparatively inaccessible in the big bank where interviews were held, as a locked door restricts access to the offices and visitors have to register at a counter.
Fig. 4: Outline of the customer advisors' offices at the savings bank

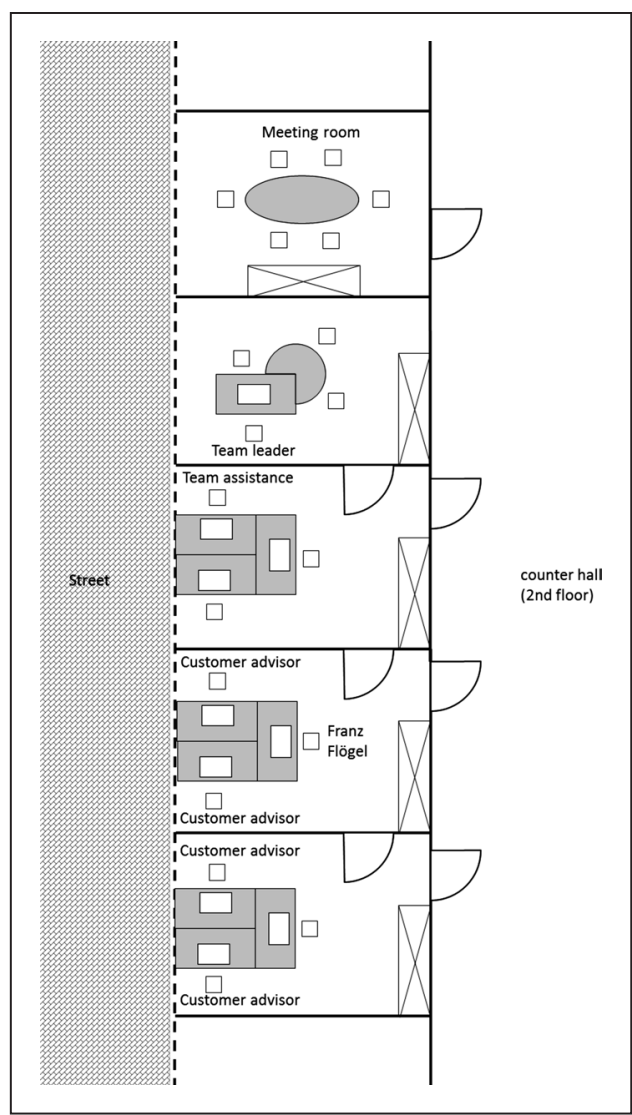

Source: own draft

The example of the bank-firm relationship was selected because it clearly shows how distance depends on both the (human) perspectives with which customer advisors view their customers and the physical design of the branch. Of course a savings bank's branch is literally a human construction and may have been purposefully designed to be accessible. Nevertheless, the ability of the customers to easily access the customer advisors constitutes a given fact for the latter which they have to bear in mind when dealing with their customers.

\section{Rating systems integration in banks' credit granting processes and performativity}

The empirical study showed that the SME rating models do not fundamentally differ between the 
savings banks and the German big bank where interviews were held, because, among other factors, German banking supervision has certified both ratings for the calculation of regulatory capital requirements. However, striking differences were detected concerning the integration of the rating systems in the credit-granting process. The analysed big bank defines a strict cut-off limit. If firms have sound rating scores $(\mathrm{PD}<2.1 \%)$ the customer advisors can grant credits of up to 1 Mio. $€$. However, if the rating score is poor ( $\mathrm{PD}>3.6 \%$ ) the bank rejects new credit applications from small firms almost irreversibly. In contrast, the observed savings bank defines no cut-off limit for firms, with the explicit aim of maintaining flexibility in credit decisions. High-level supervisors have to approve the credit applications of firms with poor rating scores. Also, customer advisors' decision-making power for firms with sound rating scores remains much lower at the savings bank than at the big bank. Therefore, normally more than one employee gets involved in the savings bank's credit decisions.

The two observed banks also differ regarding their checking of the rating execution. The big bank has not implemented an obligatory checking of customer advisors' rating execution. If the rating score remains below PD $2.1 \%$, the customer advisor and the rating system - "die Maschine" - conduct the credit decision of up to 1 Mio. $€$ autonomously. Due to the importance of the rating score for credit decisions and the absence of checking, the rating execution should be prone to manipulation. The interviewed team leader responded to this suggestion negatively: "Well, I hope none of my people is so stupid, I have never experienced this" (Interview 1, author's translation. He further explained that the bank's internal auditing randomly checks these credit decisions. In contrast to this, the credit officers of the savings bank check every rating that the customer advisors execute.

These differences in the integration of the rating systems imply that the customer advisors of the savings bank normally have to interact with several actors when making credit decisions. In contrast, over $50 \%$ of all regular SME credit decisions made by the big bank are conducted by the customer advisors and the rating system alone. The high relevance of the rating score and the less frequent checking of the rating execution should make the big bank's rating systems more prone to counterperformativity, because manipulation within the rating execution pays out. BERG et al. (2013) empirically prove for another big bank that bankers manipulate the rating execution to gain rating scores above cutoff limit. However, the interviewed team leader of the big bank denied the likelihood of this deduction. At the savings bank the rating score only allocates decision-making power and does not restrict credit decisions. Nevertheless, rating scores may not be neutral but cause "effective" performativity. One interview partner from the rating system provider of the savings banks indicated this:

"Interviewer: Is the statement true that at the end of the day the CEO can decide everything if he wants to? Answer: Yes, I think so. But of cause he needs more, more and more arguments and better arguments, because there are more guidelines and more and more, like I said concerning the topic of rap [risk adjusted pricing]; if the system calculates an interest rate, then it has to be very well justified, why this interest rate is not charged, as if no interest rate had been calculated at all. Therefore, I think it has become more difficult, because more things have to be documented, good arguments are needed as to why certain things are perhaps done and at which price and so on. So this is certainly a little bit more difficult but I think this is also right, to have really good reasons, and if it seems certain that this is a good deal and so on then nobody says it is not allowed, but it has to be justified, why the business is conducted and maybe that should have already been a requirement in the past." (Interview 2, author's translation)

\section{Discussion: the additional benefit of the new realist ontology in empirical work}

The empirical findings presented indicate that micro-geographical accessibility can be a relevant aspect of the distance between banks and firms and that the rating system integration of the big bank should be more prone to counterperformativity. Nevertheless, the rating system of the savings banks also causes "effective" performative effects despite the fact that the savings bank in question defines no strict cut-off limit. The new realist ontology adds nothing to these findings but the assurance that the usage of both seemingly metatheoretical contradicting theories can be reconciled ontologically. GABRIEL (2015) insists that one should not confuse new realist ontology with metaphysics. Hence, like all other theories, its explanatory power remains 
restricted to its FoS (ontology). Hereby, new realist ontology shows that it can equally be the fact that an economic theory provides a good description of actual economic processes, and that this very theory causes performative effects on the economic processes it describes. To rephrase GABRIEL's (2015, $354 \mathrm{ff}$.) statement, research is in the world and of the world, or more precisely some regions of the world, because the world as a totality of everything does not exist.

The combined usage of the theory on distance and small-firm lending and the theory on the performativity of economics helps to understand bank-based small-firm lending, the FoS of interest. The former theory points out that when considering the use of soft information in credit decisions, not only distance between actors matters but also the decision-making power of the actors involved. The latter theory and the empirical findings indicate that rating models can influence credit decisions even if banks define no strict cut-off limit, because of "effective" performativity. Thus, even if customer advisors possess unrestricted decision-making power, the rating scores of firms may influence their credit decisions. Therefore, in order to understand the actual credit decision practices of modern banks one needs to analyse both geographical distance (including micro-geography) and the integration in and effects of the rating systems in credit-granting processes.

Ontologically both aspects (spatial distance and rating systems) appear as objects in the FoS of bank-based small-firm lending because they influence credit decisions of banks as the ethnographical findings indicate. At the same time each of these aspects specify a separate FoS where objects like open doors, by dropping customers, rating models and bankers' orientation on the rating scores of firms appear, for example. Determining the importance of each of these objects for credit decision remains an empirical question that the ethnographical study cannot answer. More research is needed for which the new realist ontology promises to provide a metatheoretical foundation that allows a combination of diverse theories and their corresponding methods.

\section{Conclusion}

This paper argues that the seemingly metatheoretical contradictions of (some) realist econom- ic theories and (some) rather anti-realist SSoF theories popular in financial geography can be overcome by the new realist ontology. Hence, researchers may combine theories from both research traditions in empirical studies. GABRIEL's $(2013 ; 2015)$ new realist ontology argues that it is not justifiable to reject either the existence of the world of things or the existence of the world of thought. Radical constructivism and (material) metaphysics each make one of these assumptions. However, this ontological claim provides one more perspective - the world of things - in comparison to radical constructivism. How can researchers then deduce truthful findings based on the new realist ontology? The concept of FoS handles this problem. Everything that exists does so in certain FoS, whereby FoS themselves only exist because they appear in other FoS. Consequently, all findings can only be true in certain FoS. However, in contrast to radical constructivism, GABRIEL (2015) insists on the position that individuating FoS is not only the product of human cognition but is also governed by plural senses. Yet, no overall rule to individuate FoS exists. For example, if an astrophysicist states that humankind is very unimportant because of the endless universe he truly confuses his FoS of physics with the FoS of humankind.

This paper shows that neither the realist theory on distance in small-firm lending nor the rather anti-realist theory on the performativity of economics contradicts the new realist ontology. Interestingly, the theory on the performativity of economics actually requires the new realist ontology since it needs both possible market results independent of the models and the models (spectators' perspectives on the market results) that cause strong performativity. Finally, with the ethnographical banking study this paper illustrates that using both theories together in empirical research advances our understanding of modern banking.

Against this background the new realist ontology promises to be an ontological foundation for researchers in modern finance that want to use theories and methods from both research traditions, the rather realist economic and the rather anti-realist SSoF. Nonetheless, this conclusion remains a preliminary one in several ways. Firstly, this paper did not relate the new realist ontology to metatheoretical accounts in geography like moderate forms of constructivism and pragmatism. Thus the connectivity of the new realist ontology to this extensive research 
in human geography remains unaddressed. Secondly, this paper only very briefly outlines criticism of the new realist ontology, which the novelty of the ontology partly explains. And thirdly, this paper discusses the accordance of only two theories with the new realist ontology and illustrates the combined use of these theories with only one empirical example. These theories and the example have obviously been selected to support the line of argument. Likely, not all (post-dualist and realist) theories accord with the new realist ontology, as they may rely on radical constructivist assumptions or metaphysical ambition. It is important to remember in this light that the new realist ontology is not a metaphysical theory capable of explaining everything. It rather denies that a theory of everything exists, a position that demands plural theoretical work and empirical research. Thus, the new realist ontology approves the empirically grounded application, combination and future development of diverse theories, which represent a key characteristic of research in financial geography.

\section{Acknowledgment}

This work was supported by a scholarship from the Studienstiftung des deutschen Volkes. I would like to acknowledge this support and thank Hans-Martin Zademach, Christoph Scheuplein, Sebastian Hillebrand, Martina Brandt, Katharine Thomas, Caroline Flögel and two anonymous referees for their valuable comments on an earlier version of this paper.

\section{Notes}

1 Proper property is "[...] a property reference to which puts one in a position to distinguish one object in a domain from another" (GABRIEL 2015, 43).

2 Importantly, the new realist ontology does not deny that empirical findings about some FoS can be false. However, "[f]allibility alone does not generalise to any form of scepticism or radical doubt. It just means that there are all sorts of conditions of failure" (GABRIEL 2015, 321).

3 Svetlova $(2012,419)$ interprets MacKenzie's performativity theory in this way: "The application of financial models not only informs and influences professional practices (generic and effective performativity) but also shapes markets by creating (or increasing) a fit between the real (market) world and the model world (Barnesian performativity).“

4 I observed several times the difficulties customer advisors have in telling their customers of a negative bank decision in a face-to-face conversation, e.g. the rejection of an important loan or the rejection of renegotiations.

\section{Interviews}

Interview 1 (25.9.2013): German big bank, team leader. Interview 2 (30.5.2013): S-Rating und Risikosysteme GmbH, team leader.

\section{Literature}

Agarwal, S. / Hauswald, R. (2007): Distance and Information Asymmetries in Lending. Chicago (Working Paper).

Ahnert, S. / Engel, M. / Rohleder, G.(2009): Handbuch Firmenkreditgeschäft. Stuttgart.

Alessandrini, P./Fratianni, M./Zazzaro, A. (Eds.) (2009): The changing geography of banking and finance. New York. Berg, T. / Puri, M. / Rocholl, J. (2013): Loan officer incentives and the limits of hard information. Cambride, MA (Working Paper).

Berger, A. / Miller, N. / Petersen, M. / Rajan, R. / Stein, J. (2005): Does function follow organizational form? Evidence from the lending practices of large and small banks. In: Journal of Financial Economics, (76)2, 237-269.

BERndT, C. (2011): Märkte, Monster, Modelle - kulturelle Geographien der Subprimekrise. In: Zeitschrift für Wirtschaftsgeographie, (55)1-2, 35-49.

Berndt, C. / Böckler, M. (2009): Geographies of circulation and exchange: construction of markets. In: Progress in Human Geography, (33)4, 535-551.

Boghossian, P.A. (2013): Angst vor der Wahrheit. Ein Plädoyer gegen Relativismus und Konstruktivismus. Berlin.

Воот, A.W.A. (2000): Relationship banking: What do we know? In: Journal of Financial Intermediation, (9)1, 7-25.

Callon, M. (1999 [1987]): Some elements of a sociology of translation: domestication of the scallops and the fishermen of St. Brieuc Bay. In: Biagioli, M. (Ed.): The science studies reader. New York, 67-83.

CALlon, M. (1998): Introduction: The embeddedbess of economic markets in economics. In: Callon, M. (Ed.): The laws of the markets. Oxford, 1-57.

Christophers, B. (2013): Banking across boundaries. Placing finance in capitalism. Chichester, Malden.

EGNER, H. (2010): Theoretische Geographie. Darmstadt.

Engelen, E. / Erturk, I. / Froud, J. / Leaver, A. / Williams, K. (2010): Reconceptualizing financial innovation: frame, conjuncture and bricolage. In: Economy and Society, (39)1, 33-63.

FERRARIS, M. (2014): Manifest des neuen Realismus. Frankfurt am Main.

GABriel, M. (2013): Warum es die Welt nicht gibt. Berlin.

GABriel, M. (2014): Existenz, realistisch gedacht. In: Gabriel, M. (Hrsg.): Der Neue Realismus. Berlin, 171-199.

GABRIEL, M. (2015): Fields of sense. A new realist ontology. Edinburgh.

GÄRTNER, S. (2009): Sparkassen als Akteure der regionalen Strukturpolitik. In: Zeitschrift für Wirtschaftsgeographie (53) $1-2,14-27$. 
GÄRTNER, S. / FLÖGEL, F. (2013): Dezentrale versus zentrale Bankensysteme? Geographische Marktorientierung und Ort der Entscheidungsfindung als Dimensionen zur Unterteilung von Bankensystemen. In: Zeitschrift für Wirtschaftsgeographie, (57)3, 34-50.

HaLL, S. (2006): What counts? Exploring the production of quantitative financial narratives in London's corporate finance industry. In: Journal of Economic Geography, (6)5, $1-18$.

HANDKE, M. (2011), Die Hausbankbeziehung. Institutionalisierte Finanzierungslösungen für kleine und mittlere Unternehmen in räumlicher Perspektive. Münster.

JöNS, H. (2006): Dynamic hybrids and the geographies of technoscience. Discussing conceptual resources beyond the human/non-human binary. In: Social and Cultural Geography, (7)4, 559-580.

Klagge, B. / Martin, R. (2005): Decentralized versus centralized financial systems: Is there a case for local capital markets? In: Journal of Economic Geography, (5)4, 387421.

KLAGGE, B. (2009): Finanzmärkte, Unternehmensfinanzierung und die aktuelle Finanzkrise. In: Zeitschrift für Wirtschaftsgeographie, (53)1-2, 1-13.

Koch, A. F. (2014): Wir sind kein Zufall. Die Subjektivitätsthese als Grundlage eines hermeneutischen Realismus. In: Gabriel, M. (Hrsg.): Der Neue Realismus. Berlin, 230-243. MacKenzie, D.A. (2006): An engine, not a camera. How financial models shape markets. Cambridge, MA.

MacKenzie, D.A. (2011): The credit crisis as a problem in the sociology of knowledge. In: American Journal of Sociology, (116)6, 1778-1841.

MacKenzie, D. A. / Millo, Y. (2003): Constructing a market, performing theory. The historical sociology of a financial derivatives exchange. In: The American Journal of Sociology, (109)1, 107-145.

Mattissek, C. / Pfaffenbach, C. / Reuber, P. (2012): Methoden der empirischen Humangeographie. Braunschweig.

Murdoch, J. (1996): Inhuman/nonhuman/human. Actornetwork theory and the prospects for a nondualistic and symmetrical perspective on nature and society. In: Environment and Planning D, (6)15, 731-756.

Ouma, S. (2012): „Markets in the Making“. Zur Ethnographie alltäglicher Marktkonstruktionen in organisationalen Settings. In: Geographica Helvetica, (67)4, 203-211.

OumA, S. / BLÄSER, K.(2015); Räume der Kalkulation, Kalkulation des Raumes. Geographien der finanziellen Ökonomisierung. In: Zeitschrift für Wirtschaftsgeographie, 59(4), 214-229.
Poon, M. (2007): Scorecards as devices for consumer credit. The case of Fair, Isaac \& Company Incorporated. In: Callon, M. / Millo, Y. / Muniesa, F. (Eds.): Market devices. Malden, 284-306.

RAJAN, U. / SERU, A. / VIG, V. (2010): The failure of models that predict failure. Distance, incentives and defaults. Chicago. (Chicago GSB Research Paper).

RónA-TAS, Á./HISS, S. (2008): Consumer and corporate credit ratings and the subprime crisis in the U.S. with some lessons for Germany. Wiesbaden.

Schamp, E. / Linge, G. J.R. / Rogerson, C. (Eds.) (1993): Finance, institutions and industrial change. Spatial perspectives. Berlin.

Scheuplein, C. (2013): Eine empirische Analyse von Buyouts und Standortstrukturen der Private-Equity-Firmen in Deutschland. In: Zeitschrift für Wirtschaftsgeographie, (57)4, 201-215.

SvetLova, E. (2012): On the performative power of financial models. In: Economy and Society, (41)3, 418-434.

STEIN, J. (2002): Information production and capital allocation. Decentralized versus hierarchical firms. In: The Journal of Finance, (57)5, 1891-1921.

SteIner, C. (2014a): Pragmatismus - Umwelt - Raum. Potenziale des Pragmatismus für eine transdisziplinäre Geographie der Mitwelt. Stuttgart.

STEINER, C. (2014b): Von Interaktion zu Transaktion - Konsequenzen eines pragmatischen Mensch-Umwelt-Verständnisses für eine Geographie der Mitwelt. In: Geographica Helvetica, (69)3, 171-181.

Thомi, W. / OssenbrügGe, J. (Hrsg.) (2011): Risikofaktor Finanzmärkte. In: Zeitschrift für Wirtschaftsgeographie, (55)1-2, 1-4.

UChida, H./ Udell, G. F. / YAmori, N. (2012): Loan officers and relationship lending to SMEs. In: Journal of Financial Intermediation, (21)1, 97-122.

Werlen, B. (1997): Gesellschaft, Handlung und Raum. Grundlagen handlungstheoretischer Sozialgeographie. Stuttgart.

WOORDARD, K. / JONES, J.P. (2009): Ontology. In: Gregory, D. (Ed.): The dictionary of human geography. Malden, 511-513.

ZADEMACH, H.-M. (2009): Global finance and the development of regional clusters. Tracing paths in Munich's film and TV industry. In: Journal of Economic Geography, (9)5, 697-772.

Zademach, H.-M. (2014): Finanzgeographie. Darmstadt. 